\title{
Labor earnings reductions, happiness levels and needs hierarchy
}

\author{
Stavros Drakopoulos · Katerina Grimani
}

\begin{abstract}
One of the main economic outcomes of the recent Great Recession has been the decrease of labor earnings in many countries. The relevant literature indicates that earnings and other socioeconomic predictors can influence levels of happiness. This paper tests the effect of pay cuts on happiness levels based on the psychological model of hierarchical needs. The basic idea of hierarchy is that the most important needs must be satisfied first before the secondary needs come into the picture. In a happiness research framework, this implies that for higher income levels, the effect of pay cuts on reported happiness levels becomes much weaker, given that the satisfaction of non-basic needs becomes important. The data used in this paper was drawn from the 5th European Survey on Working Conditions, which focuses on European countries. Two different disaggregation methods were performed, based on absolute nominal income threshold and relative income threshold, respectively. The methods for analyzing the data are the ordinary leastsquares (OLS) regression model, and the Wald chi-square test. The pay cuts are a stronger predictor of happiness for low/middle income individuals than for high income individuals when it comes to disaggregation based on absolute threshold. The regression coefficients of pay cuts for the low/middle income group were not significantly different from those for the high income group regarding disaggregation based on relative threshold. The results seem to depend on the disaggregation method, implying the need for further research and discussion.
\end{abstract}

Keywords: pay cuts, happiness, subjective wellbeing, Maslow's Hierarchy of Needs

\section{Introduction}

One of the main characteristics of the Great Recession of 2008 was the reduction of labor earnings in many countries for a substantial number of employees (Jenkins et al., 2013). Apart from the obvious effects of pay cuts on the purchasing power and living standards of individuals and households, falling labor earnings must also affect happiness levels, given that rising income has been shown to have a positive relationship to happiness (Sloane \& Williams, 2000; Helliwell, 2003; Gasper, 2005; Clark et al., 2008; Stutzer \& Frey, 2010). Happiness (or life satisfaction) has been defined as a combination of feeling good (hedonic perspective) and functioning effectively (eudemonic perspective). The hedonic component is concerned with subjective experiences of pleasure, while the eudemonic component is concerned with fulfillment and the realization of human potential and actualization (Deci \& Ryan, 2008; Steptoe et al., 2008; Huppert, 2009). Understanding the happiness (or job satisfaction) of employees is important because work exhibits a substantial psychological dimension for self-identity and sense of purpose, given that adults spend an average of about 33.6 hours per week at work (Kahneman et al., 2004; Tay \& Harter, 2013). Improving the happiness levels of the workforce has important social and economic effects, since it brings benefits for both the employees and the organization, and

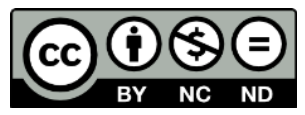

Copyright belongs to the author(s) www.internationaljournalofwellbeing.org 
influences an individual's social behavior, employment relations and productive performance in the workplace (Danna \& Griffin, 1999; Lyubomirsky et al., 2005; Grant et al., 2007; Panos \& Theodossiou, 2007; Wesarat et al., 2015). High levels of psychological wellbeing at the workplace allow employees to flourish and achieve their full potential for the benefit of themselves and their organization (Grant et al., 2007; Wesarat et al., 2015). In empirical work, reported subjective wellbeing is taken as a proxy measure for individual welfare and individual happiness (see Stutzer \& Frey, 2010). In this study, the terms life satisfaction, subjective wellbeing, and happiness are used interchangeably, as is the usual practice in most recent studies (see also the discussion in La Placa et al., 2013).

The paper examines the relatively under-researched topic of labor earnings reductions and its relationship to happiness levels. Based on Maslow's psychological theory of hierarchical needs (Maslow, 1954), the paper argues that labor earnings are very important for happiness up to a certain level of income. The incorporation of the needs hierarchy into a happiness framework implies that individuals have a priority approach to happiness in relation to income. The crucial point here is that the most important needs must be satisfied first before the secondary needs come into the picture. It follows that forra higher income levels the effect of pay cuts on reported happiness levels becomes much weaker, given that the satisfaction of non-basic needs becomes important.

In this work, the above idea is tested by employing data drawn from the 5th European Survey on Working Conditions (2010). The structure is as follows: Section 2 will present a literature survey concerning happiness and its relationship to labor earning changes. It will also discuss the incorporation of Maslow's needs hierarchy approach into the framework of happiness research. The following sections will concentrate on the data and the empirical methodology, as well as the main research findings. A conclusion will close the paper.

\section{Literature review}

\subsection{Happiness and labor earning changes}

Aristotle has been cited as the first written source of the idea that all human action is implicitly motivated by a desire to increase individuals' subjective wellbeing or eudemonia, which referred to specific psychological experiences that were seen as the essence of a good life (Deci \& Ryan, 2008). Modern rational choice theory suggests that revealed preferences imply motivation which means that individuals who strive for money believe (at some conscious or unconscious level) that it will increase their happiness (Ahuvia, 2008). ${ }^{1}$ Accordingly, the existing empirical research reveals that the richer countries declare higher levels of happiness compared to poorer countries, and within each country, the richer members of society are happier than the poor. In particular, several studies have suggested that higher income is associated with greater life satisfaction (see for instance: Easterlin, 1995; Helliwell, 2003; Liu et al., 2010). On the other hand, time-series analyses show that higher per capita incomes have failed to generate any noticeable improvement in happiness levels in most developed countries (e.g., Blanchflower \& Oswald, 2004; Easterlin \& Angelescu, 2012). Although within a country at a given time those with higher incomes are, on average, happier, many studies have found that raising the incomes of all does not increase the happiness of all. This presents researchers with a paradox, termed usually as the happiness or the Easterlin paradox (Easterlin, 1995; 2001; Cummins, 2000; Mentzakis \& Moro, 2009; Diener et al., 2013).

\footnotetext{
${ }^{1}$ Similarly, recent evidence from psychology suggests that high levels of income are also associated with lower levels of psychopathology (e.g., Wood et al. 2012).
} 
With these findings in mind, it is reasonable to assume that wage cuts would have the opposite effects on happiness levels. In fact, the effect might be stronger than pay rises, according to the notion of loss aversion, which implies that "losses loom larger than gains." This concept originated in the work of Kahneman and Tversky (1979), and has since been shown to be useful in a range of real-world contexts (for example, Camerer, 2000). In particular, under experimental conditions, a loss is typically estimated to have twice the influence on decisions as equivalent gains (Novemsky \& Kahneman, 2005). However, there is not much relevant work examining the effects of wage cuts on happiness levels. One plausible explanation for this might be that until the Great Recession of 2008, nominal wage cuts was a rare and rather isolated phenomenon in most Western countries. One of the few papers that has employed this idea in the subjective wellbeing framework found that experienced drops in income have a larger impact on wellbeing than equivalent income gains (Boyce et al., 2013). Similarly, a recent working paper found that measures of life satisfaction and affect are more than twice as sensitive to negative economic growth as compared to positive growth (De Neve et al., 2015). However, another recent paper reported mixed results concerning the presence of loss aversion, and suggested that the relationship between pay growth and job satisfaction is less steep for cuts than for raises (Smith, 2015). Furthermore, according to Drakopoulos and Grimani (2015), pay cuts have a highly significant negative effect on psychological wellbeing and job satisfaction. This work aims to provide some additional insights into these relationships.

\subsection{Labor earning changes and hierarchical behaviour}

Hierarchical choice consists of two interconnected central ideas: the first is that human needs are of varying importance, and the second is that human needs must be satisfied in a specific order. These two ideas imply that there are primary needs and secondary needs that cannot be substituted. According to Maslow (1954), primary needs refer mainly to physical needs like the need for food, clothing and shelter, while secondary needs refer to intellectual or non-material needs (for a discussion of the definition of primary and secondary needs, see Drakopoulos, 1994; Max-Neef, 1995; Gasper, 2005). The hierarchical approach predicts that when income is very low, a very high percentage of it would be spent on food, since food satisfies a basic need. This is in line with the hypothesis that consumption evolves along a hierarchical order as income increases. The hierarchical model has been applied to a wide array of economic issues (see for instance, Lluch et al., 1977; Canterbery, 1979; Jackson \& Marks, 1999; Thiele \& Weiss, 2003; Canova et al., 2005; Chattopadhyay et al., 2009). However, the application of hierarchical choice to happiness research has not received much attention.

In our framework, hierarchy implies that once a level of labor earnings that satisfies the basic needs has been reached, further changes of labor earnings do not provide analogous changes on happiness levels because secondary needs come into the picture (Clark \& Oswald, 1996; Drakopoulos \& Theodossiou, 1997; Drakopoulos, 2013). Taking into account the notion of earnings that satisfy basic needs, an employee's happiness level can be written as:

$$
\mathrm{H}=\mathrm{H}\left(\mathrm{LE}, \mathrm{LE}^{*}, \mathrm{X}\right)
$$

where $\mathrm{H}$ is happiness, $\mathrm{LE}$ is the level of labor earnings, $\mathrm{LE}^{*}$ is the level of labor earnings which satisfies basic needs, and $X$ is a vector of characteristics comprising variables that affect happiness. The inclusion of the threshold level of labor earnings LE* in equation (1) reflects the 
essence of hierarchy. ${ }^{2}$ The other variables $(X)$ satisfy secondary needs and are taken into consideration only when LE reaches a satisfactory level or target LE*. (For a discussion concerning the determination of $\mathrm{LE}^{*}$, see Ferrer-i-Carbonell 2005.) We can incorporate all the above by taking a two-part function:

$$
\mathrm{H}(\mathrm{LE}, \mathrm{X})=\left\{\mathrm{H}^{\mathrm{L}}(\mathrm{LE}, \mathrm{X}), \mathrm{H}^{\mathrm{H}}(\mathrm{LE}, \mathrm{X})\right\}
$$

where

$$
H(L E, X)=H^{L} \text { for } L E \leq L E^{*} \quad \text { and } \quad H(L E, X)=H^{H} \text { for } L E>L E^{*}
$$

with the following conditions (which are also our hypotheses to be tested in the empirical part of the paper):

$$
\frac{\partial \mathbf{H}^{\mathrm{L}}}{\partial \mathrm{LE}}>\mathbf{0}, \frac{\partial \mathbf{H}^{\mathrm{H}}}{\partial \mathbf{L E}}>\mathbf{0} \quad \text { and } \quad \frac{\partial \mathbf{H}^{\mathrm{L}}}{\partial \mathrm{LE}}>\frac{\partial \mathbf{H}^{\mathrm{H}}}{\partial \mathrm{LE}}
$$

The conditions provide the essence of the hierarchical approach to happiness levels. The first two conditions imply that labor earnings have a positive effect on happiness levels. The last condition infers that labor earnings do not provide the same rate of happiness levels once a given level $\left(\mathrm{LE}^{*}\right)$ has been reached, suggesting that other factors start playing a role with regard to the level of happiness. Thus, falling labor earnings affect significantly and in a negative manner the happiness levels of the group of lower/middle income workers, while for the group of higher income workers, the effect of pay cuts on reported happiness levels becomes much weaker. In other words, falling earnings have an asymmetric effect on happiness, depending on the category of income. In the following sections of this paper, we will test this idea by using a large European dataset.

\section{Empirical analysis}

\subsection{Data and participants}

The data used in this paper was drawn from the 5th European Survey on Working Conditions, ${ }^{3}$ which aimed to provide a comprehensive picture of the everyday reality of men and women at work. The research was conducted in the first half of 2010 (face-to-face interviews in people's homes in the national language(s) of the country) and contains data from 33 European countries and Turkey. Given our focus in this paper, the timing of the survey was two years after the financial crisis of 2008, when the phenomenon of nominal pay cuts became much more widespread in many European countries. Thus, the 5th wave of 2010 captures very well the substantial occurrence of pay cuts in contrast to pre-2008 waves.

The target sample size of 1,000 interviews was set for most countries. The participants were aged 15 or older, were in employment at the time of the survey, and were selected by the method of multi-stage stratified random sampling. They responded to a questionnaire of about 44 minutes' duration, comprising 89 questions relating to issues such as work time duration, work organization, learning and training, physical and psychosocial risk factors, health and safety,

\footnotetext{
${ }^{2}$ The inclusion of $\mathrm{LE}^{*}$ and the two-part function implies a kink at $\mathrm{LE}^{*}$, and this is the main difference from the standard diminishing marginal utility approach, which gives one smooth function.

${ }^{3}$ Further information on the project can be found at www.eurofound.europa.eu/surveys/ewcs/index.htm.
} 
work-life balance, worker participation, earnings and financial security. A number of questions were included to capture the effect of the economic downturn on working conditions.

The questionnaire data of interest included happiness and labor earning changes variables. It also included type of occupation (four dummy variables: high skilled clerical, low skilled clerical, high skilled manual, low skilled manual), previous occupational status (seven dummy variables: employed with an indefinite contract, employed with a fixed-term contract, employed with a temporary employment agency contract, employed, unemployed, in education or training, other), and working hours per week. The participants were working adults aged 18 to 65. In terms of countries, the sample consisted of 34 dummy variables: Albania, Austria, Belgium, Bulgaria, Croatia, Cyprus, Czech Republic, Denmark, Estonia, Finland, France, Germany, Greece, Hungary, Ireland, Italy, Kosovo, Latvia, Lithuania, Luxembourg, Former Yugoslav Republic of Macedonia (FYROM), Malta, Montenegro, the Netherlands, Norway, Poland, Portugal, Romania, Slovakia, Slovenia, Spain, Sweden, Turkey, and the United Kingdom. Finally, the data contained personal variables such as age and age squared, gender and educational level (three dummy variables: none and primary education, secondary, including lower, upper and post-secondary education, and tertiary, including advanced level of tertiary education).

The happiness variable covers five positively worded items related to positive mood (good spirits, relaxation), vitality (being active and waking up fresh and rested) and general interests (being interested in things), all experienced over the previous two weeks. This five-item World Health Organization Well-Being Index (WHO-5) is among the most widely used questionnaires assessing subjective psychological wellbeing with high clinimetric validity. Since its first publication in 1998, the WHO-5 has been translated into more than 30 languages and has been applied successfully across a wide range of study fields (see, for instance Topp et al., 2015; Schutte et al., 2014; Sisak et al., 2008; Gill \& Feinstein, 1994). The WHO-5 was derived from the WHO-10, which in turn was derived from a 28-item rating scale (selected from the Zung scales for depression, distress and anxiety, as well as from the General Health Questionnaire and the Psychological General Well-Being Scale), on the basis of a non-parametric item response theory analysis. The new version identified the 10 most valid items from the original 28 -item scale (Bech, 1993). Each of the five items is rated on a 6-point Likert scale from 1 (= at no time) to 6 (= all of the time). In addition, the five scores created an index, which was linearized by using z-scores transformation. The negative values of the z-scores were transformed into positive and the natural logarithm $(\mathrm{ln})$ was estimated. Reliability and validity estimations were conducted prior to index variable construction. The internal consistency approach (Cronbach's alpha) was employed in order to assess the reliability of the scale. According to the results, the Cronbach's alpha of the Psychological General Well-Being Scale was 0.8814. This suggests that the internal reliability of the scale is high, since an instrument with an internal consistency coefficient of 0.80 (scale total) or higher is considered to be adequate (Cronbach, 1951; Nunnaly, 1978). The validity of the scale was assessed by construct validity, using factor analysis. The results are considered to be satisfactory, since the loadings were far from 0 and the uniqueness was less than 0.50 . The labor earning changes variable was assessed, reporting a change in their salary, comparing their current situation with that of a year ago (three dummy variables: pay cuts (decrease in labor earnings), no change in labor earnings, increase in labor earnings, see Table 1 below).

The theoretical model that we follow implies that the sample has to be disaggregated into two categories: low/middle and high income. There is no standard definition of high income threshold in the relevant literature. Absolute nominal thresholds and relative thresholds are the two main methods found in most works on income levels (see Murphy et al., 2007). Both the "relative threshold cutoff," based on median or mean income, and absolute nominal income threshold are widely used approaches (e.g., Morissette \& Zhang, 2006; Murphy et al., 2007). 
Table 1. Definitions of variables

\begin{tabular}{ll}
\hline & Variables/Definitions \\
\hline Ln Happiness levels & France $=1$, otherwise $=0$ \\
Ireland $=1$, otherwise $=0$ & Italy $=1$, otherwise $=0$ \\
Males $=1$, Females $=0$ & Luxembourg $=1$, otherwise $=0$ \\
Age $(18-65$ years $)$ & Netherlands $=1$, otherwise $=0$ \\
Age 2 & UK $=1$, otherwise $=0$ \\
Primary education $=1$, otherwise $=0$ & Bulgaria $=1$, otherwise $=0$ \\
Secondary education $=1$, otherwise $=0$ & Cyprus $=1$, otherwise $=0$ \\
Tertiary education $=1$, otherwise $=0$ & Czech Republic $=1$, otherwise $=0$ \\
Low skilled manual $=1$, otherwise $=0$ & Estonia $=1$, otherwise $=0$ \\
Low skilled clerical $=1$, otherwise $=0$ & Hungary $=1$, otherwise $=0$ \\
High skilled manual $=1$, otherwise $=0$ & Latvia $=1$, otherwise $=0$ \\
High skilled clerical $=1$, otherwise $=0$ & Lithuania $=1$, otherwise $=0$ \\
Working hours per week $(1-84)$ & Malta $=1$, otherwise $=0$ \\
Pay cuts $($ decrease labor earnings $)=1$, otherwise $=0$ & Poland $=1$, otherwise $=0$ \\
No change labor earnings $=1$, otherwise $=0$ & Romania $=1$, otherwise $=0$ \\
Increase labor earnings $=1$, otherwise $=0$ & Slovakia $=1$, otherwise $=0$ \\
Belgium $=1$, otherwise $=0$ & Slovenia $=1$, otherwise $=0$ \\
Denmark $=1$, otherwise $=0$ & Turkey $=1$, otherwise $=0$ \\
Germany $=1$, otherwise $=0$ & Croatia $=1$, otherwise $=0$ \\
Spain $=1$, otherwise $=0$ & Norway $=1$, otherwise $=0$ \\
Finland $=1$, otherwise $=0$ & FYROM $=1$, otherwise $=0$ \\
Austria $=1$, otherwise $=0$ & Albania $=1$, otherwise $=0$ \\
Portugal $=1$, otherwise $=0$ & Kosovo $=1$, otherwise $=0$ \\
Greece $=1$, otherwise $=0$ & Montenegro $=1$, otherwise $=0$ \\
Sweden $=1$, otherwise $=0$ &
\end{tabular}

In this work, the relative threshold cutoff approach identifies as high income those who earn above two times the median income. This is also consistent with empirical work indicating that above this level, individuals tend to save a considerable percentage of their income, something which implies that they can comfortably cover their basic needs (Huggett \& Ventura, 2000). The application of this method gave 28,965 low/middle income individuals and 4,131 high income individuals. The disaggregation was based on the Eurostat map data of European countries of median income for the year 2010. For the three following countries: Albania, Kosovo, and Montenegro, the disaggregation was based on the Trading Economics map data for year 2010. The split performed for low/middle and high income groups is appropriate, given that the Kolmogorov-Smirnov test indicated that the income distributions are different (see Table 2a below).

An additional disaggregation, based on absolute nominal income threshold, was also conducted. The data was drawn from the World Bank map data of European countries by GDP per capita for the year 2010. The low/middle income sample contains 29,239 individuals, while the high income sample contains 3,857 individuals. We determined a threshold value for each country that was based on each country's per capita gross domestic product. 
Table 2a. Summary statistics of variables (after disaggregation by relative threshold)

\begin{tabular}{|c|c|c|c|c|}
\hline \multirow{2}{*}{ Variables } & \multicolumn{2}{|c|}{ Low/middle income levels } & \multicolumn{2}{|c|}{ High income levels } \\
\hline & Mean & SD & Mean & SD \\
\hline Ln Happiness levels & 1.040 & 0.533 & 1.082 & 0.466 \\
\hline Pay cuts (decrease labor earnings) & 0.201 & 0.400 & 0.191 & 0.393 \\
\hline No change labor earnings & 0.541 & 0.498 & 0.502 & 0.500 \\
\hline Males & 0.482 & 0.499 & 0.718 & 0.449 \\
\hline Age & 41.044 & 11.460 & 41.321 & 10.884 \\
\hline Age $^{2}$ & 1815.975 & 947.533 & 1825.854 & 920.091 \\
\hline Primary education & 0.057 & 0.232 & 0.059 & 0.235 \\
\hline Secondary education & 0.675 & 0.468 & 0.433 & 0.495 \\
\hline Working hours & 38.415 & 11.652 & 45.446 & 12.552 \\
\hline Low skilled manual & 0.193 & 0.395 & 0.091 & 0.286 \\
\hline Low skilled clerical & 0.447 & 0.497 & 0.307 & 0.461 \\
\hline High skilled manual & 0.159 & 0.366 & 0.137 & 0.344 \\
\hline Belgium & 0.089 & 0.285 & 0.028 & 0.165 \\
\hline Bulgaria & 0.023 & 0.153 & 0.014 & 0.119 \\
\hline Czech Republic & 0.022 & 0.149 & 0.021 & 0.143 \\
\hline Denmark & 0.029 & 0.168 & 0.027 & 0.163 \\
\hline Germany & 0.058 & 0.234 & 0.015 & 0.121 \\
\hline Estonia & 0.021 & 0.141 & 0.035 & 0.184 \\
\hline Spain & 0.024 & 0.155 & 0.026 & 0.160 \\
\hline France & 0.023 & 0.151 & 0.012 & 0.111 \\
\hline Ireland & 0.081 & 0.272 & 0.024 & 0.155 \\
\hline Italy & 0.022 & 0.147 & 0.035 & 0.185 \\
\hline Cyprus & 0.031 & 0.172 & 0.008 & 0.089 \\
\hline Latvia & 0.024 & 0.154 & 0.020 & 0.141 \\
\hline Lithuania & 0.023 & 0.151 & 0.023 & 0.152 \\
\hline Luxemburg & 0.021 & 0.144 & 0.019 & 0.139 \\
\hline Hungary & 0.017 & 0.131 & 0.029 & 0.167 \\
\hline Malta & 0.026 & 0.160 & 0.022 & 0.146 \\
\hline Netherlands & 0.022 & 0.149 & 0.023 & 0.151 \\
\hline Austria & 0.026 & 0.160 & 0.023 & 0.149 \\
\hline Poland & 0.022 & 0.148 & 0.004 & 0.064 \\
\hline Portugal & 0.025 & 0.156 & 0.055 & 0.228 \\
\hline Romania & 0.017 & 0.131 & 0.056 & 0.229 \\
\hline Slovenia & 0.039 & 0.194 & 0.013 & 0.113 \\
\hline Slovakia & 0.025 & 0.156 & 0.016 & 0.127 \\
\hline Finland & 0.029 & 0.168 & 0.005 & 0.067 \\
\hline Sweden & 0.025 & 0.156 & 0.027 & 0.162 \\
\hline UK & 0.028 & 0.167 & 0.031 & 0.175 \\
\hline Croatia & 0.022 & 0.148 & 0.059 & 0.235 \\
\hline FYROM & 0.028 & 0.166 & 0.007 & 0.089 \\
\hline Turkey & 0.025 & 0.157 & 0.231 & 0.421 \\
\hline Norway & 0.028 & 0.164 & 0.024 & 0.155 \\
\hline Albania & 0.023 & 0.150 & 0.017 & 0.131 \\
\hline Kosovo & 0.025 & 0.156 & 0.014 & 0.118 \\
\hline Montenegro & 0.023 & 0.151 & 0.008 & 0.091 \\
\hline Observations & \multicolumn{2}{|c|}{28965} & \multicolumn{2}{|c|}{4131} \\
\hline
\end{tabular}

The income above the given threshold value for each country has been considered as high, while the income below the given threshold value for each country has been considered as low $/ \mathrm{middle}$. The split performed for low/middle and high income groups is also appropriate, according to the Kolmogorov-Smirnov test (see Table $2 b$ below). 
Table $2 b$. Summary statistics of variables (after disaggregation by absolute nominal threshold)

\begin{tabular}{|c|c|c|c|c|}
\hline \multirow{2}{*}{ Variables } & \multicolumn{2}{|c|}{ Low/middle income levels } & \multicolumn{2}{|c|}{ High income levels } \\
\hline & Mean & SD & Mean & SD \\
\hline Ln Happiness levels & 1.031 & 0.542 & 1.151 & 0.354 \\
\hline Pay cuts (decrease labor earnings) & 0.206 & 0.404 & 0.151 & 0.358 \\
\hline No change labor earnings & 0.546 & 0.497 & 0.458 & 0.498 \\
\hline Males & 0.486 & 0.499 & 0.704 & 0.456 \\
\hline Age & 40.649 & 11.474 & 44.337 & 10.156 \\
\hline $\mathrm{Age}^{2}$ & 1784.004 & 945.019 & 2068.919 & 898.533 \\
\hline Primary education & 0.063 & 0.243 & 0.015 & 0.124 \\
\hline Secondary education & 0.679 & 0.466 & 0.385 & 0.486 \\
\hline Working hours & 38.784 & 12.036 & 43.152 & 10.931 \\
\hline Low skilled manual & 0.195 & 0.396 & 0.069 & 0.253 \\
\hline Low skilled clerical & 0.446 & 0.497 & 0.309 & 0.462 \\
\hline High skilled manual & 0.165 & 0.371 & 0.096 & 0.295 \\
\hline Belgium & 0.080 & 0.271 & 0.096 & 0.295 \\
\hline Bulgaria & 0.025 & 0.157 & 0.003 & 0.057 \\
\hline Czech Republic & 0.025 & 0.156 & 0.003 & 0.060 \\
\hline Denmark & 0.018 & 0.134 & 0.111 & 0.314 \\
\hline Germany & 0.052 & 0.223 & 0.057 & 0.231 \\
\hline Estonia & 0.024 & 0.154 & 0.007 & 0.083 \\
\hline Spain & 0.024 & 0.155 & 0.028 & 0.165 \\
\hline France & 0.022 & 0.148 & 0.019 & 0.138 \\
\hline Ireland & 0.073 & 0.260 & 0.080 & 0.271 \\
\hline Italy & 0.019 & 0.137 & 0.058 & 0.234 \\
\hline Cyprus & 0.028 & 0.167 & 0.018 & 0.133 \\
\hline Latvia & 0.021 & 0.145 & 0.040 & 0.197 \\
\hline Lithuania & 0.025 & 0.158 & 0.006 & 0.080 \\
\hline Luxemburg & 0.023 & 0.151 & 0.002 & 0.050 \\
\hline Hungary & 0.017 & 0.131 & 0.031 & 0.173 \\
\hline Malta & 0.028 & 0.166 & 0.004 & 0.068 \\
\hline Netherlands & 0.022 & 0.148 & 0.024 & 0.155 \\
\hline Austria & 0.024 & 0.155 & 0.034 & 0.182 \\
\hline Poland & 0.021 & 0.143 & 0.015 & 0.124 \\
\hline Portugal & 0.031 & 0.174 & 0.010 & 0.101 \\
\hline Romania & 0.024 & 0.155 & 0.002 & 0.045 \\
\hline Slovenia & 0.038 & 0.191 & 0.021 & 0.143 \\
\hline Slovakia & 0.026 & 0.160 & 0.006 & 0.080 \\
\hline Finland & 0.024 & 0.153 & 0.042 & 0.201 \\
\hline Sweden & 0.021 & 0.143 & 0.057 & 0.232 \\
\hline UK & 0.026 & 0.161 & 0.046 & 0.210 \\
\hline Croatia & 0.027 & 0.164 & 0.020 & 0.142 \\
\hline FYROM & 0.028 & 0.165 & 0.011 & 0.107 \\
\hline Turkey & 0.054 & 0.227 & 0.021 & 0.144 \\
\hline Norway & 0.024 & 0.155 & 0.047 & 0.213 \\
\hline Albania & 0.022 & 0.147 & 0.023 & 0.151 \\
\hline Kosovo & 0.024 & 0.155 & 0.015 & 0.122 \\
\hline Montenegro & 0.022 & 0.146 & 0.018 & 0.134 \\
\hline Observations & \multicolumn{2}{|c|}{29239} & \multicolumn{2}{|c|}{3857} \\
\hline
\end{tabular}

\section{Empirical methodology}

In the econometric specification of this paper, happiness will be the dependent variable. The variable is determined by a number of factors, including labor earning changes. The methods for analyzing psychological wellbeing data is the ordinary least-squares (OLS) regression and the Wald chi-square test (Williams, 2008; Green \& Hensher, 2010; Greene, 2012). 
Before we proceed to the report of the results, we should also mention a limitation of the present study that needs to be acknowledged. The limitation concerns the survey instrument employed, which was a self-reporting measure of happiness. This suggests that the information presented by the participants is based upon their subjective perceptions. Although participants were assured of confidentiality, it is possible that they either over- or underreported their level of happiness. However, self-reporting measures are widely used in many similar contemporary empirical studies (for instance, see Fordyce, 1988; Danna \& Griffin, 1999; Charness \& Grosskopf, 2001; Senik, 2005; Kahneman \& Krueger, 2006).

\section{Results}

In line with the theoretical part and with our discussion of the empirical methodology section, our equation of interest for the low/middle income group is:

$$
H_{i}^{L}=\alpha_{0}+\alpha_{1} L_{i}+\alpha_{2} X_{1}+\varepsilon_{1}
$$

whereas for the high income group it is:

$$
H_{i}^{H}=b_{0}+b_{1} L E_{i}+b_{2} X_{1}+\varepsilon_{1}
$$

It is assumed that employees' happiness is determined by a variety of factors. These factors are the following: LE is the labor earning changes (three dummy variables: pay cuts (decrease in labor earnings), no change in labor earnings, increase in labor earnings), which is the basic independent variable; $X$ is a vector of other individual socioeconomic variables, such as age, age ${ }^{2}$, gender, education level, type of occupation, hours of work, and country dummy variables, assumed to influence happiness levels (Ferrer-i-Carbonell, 2005; Panos \& Theodossiou, 2007; Dolan et al., 2008). The $\alpha$ and $\mathrm{b}$ are the associated coefficients, and $\varepsilon_{\mathrm{i}}$ is a normally distributed error term.

The results of the OLS regression models (with robust standard errors - Table 3a below), which are similar for both groups, reveal a statistically significant negative effect of pay cuts (decrease in labor earnings) on subjective wellbeing. After the simultaneous estimation of the results for both regression models, the Wald chi-square test was employed in order to examine whether coefficients differ across groups (Greene, 2012). Initially, there was a comparison of all of the coefficients from the two regression models. The results indicated that one or more of the coefficients significantly differ across groups $\left(\mathrm{x}^{2}(44)=89.84, \mathrm{p}<.01\right)$. Subsequently, the significance of the independent dummy variable was tested separately. The results indicated that the regression coefficients of the independent dummy variable for low/middle income group are not significantly different from those for high income group. Analogous results regarding the additional disaggregation based on absolute nominal income threshold are presented in Table $3 \mathrm{~b}$ below. One or more of the coefficients also significantly differ across groups ( $\mathrm{x} 2(44)=183.88$, $\mathrm{p}<.01)$. However, the regression coefficients of the independent dummy variables for low/middle income group are significantly different from those for high income group $(x 2(1)=$ $4.15, \mathrm{p}<.05)$, suggesting that labor earning changes is a stronger predictor of happiness for the first group than for the latter. 
Table 3a. Dependent variable - Ln Happiness levels: Simultaneous results for regression models (after disaggregation by relative threshold)

\begin{tabular}{|c|c|c|c|c|}
\hline \multirow{2}{*}{$\begin{array}{l}\text { Variables } \\
\text { Pay cuts (decrease labor earnings) }\end{array}$} & \multicolumn{2}{|c|}{ Low/middle income group } & \multicolumn{2}{|c|}{ High income group } \\
\hline & -0.106 & $(-10.60)^{* *}$ & -0.095 & $(-4.18)^{* *}$ \\
\hline No change & 0.005 & $(0.73)$ & 0.009 & $(0.55)$ \\
\hline Males & 0.070 & $(10.47)^{* *}$ & 0.053 & $(3.24)^{* *}$ \\
\hline Age & -0.009 & $(-5.24)^{* *}$ & -0.012 & $(-2.36)^{*}$ \\
\hline $\mathrm{Age}^{2}$ & 0.000 & $(3.73)^{* *}$ & 0.000 & $(2.23)^{*}$ \\
\hline Primary education & -0.079 & $(-4.80)^{* *}$ & -0.112 & $(-3.09)^{* *}$ \\
\hline Secondary education & -0.003 & $(-0.38)$ & 0.012 & $(0.68)$ \\
\hline Working hours & -0.001 & $(-2.86)^{* *}$ & -0.003 & $(-4.68)^{* *}$ \\
\hline Low skilled manual & -0.112 & $(-9.97)^{* *}$ & -0.071 & $(-2.47)^{*}$ \\
\hline Low skilled clerical & -0.028 & $(-3.17)^{* *}$ & -0.032 & $(-1.78)$ \\
\hline High skilled manual & -0.044 & $(-3.74)^{* *}$ & 0.005 & $(0.19)$ \\
\hline Belgium & 0.065 & $(2.72)^{* *}$ & 0.063 & $(0.93)$ \\
\hline Bulgaria & -0.082 & $(-2.77)^{* *}$ & -0.005 & $(-0.07)$ \\
\hline Czech Republic & -0.114 & $(-3.86)^{* *}$ & -0.085 & $(-1.19)$ \\
\hline Denmark & 0.194 & $(6.88)^{* *}$ & 0.178 & $(2.63)^{* *}$ \\
\hline Germany & 0.086 & $(3.43)^{* *}$ & 0.060 & $(0.77)$ \\
\hline Estonia & 0.057 & $(1.86)$ & 0.055 & $(0.86)$ \\
\hline Spain & 0.072 & $(2.50)^{*}$ & 0.093 & $(1.37)$ \\
\hline France & 0.197 & $(6.78)^{* *}$ & 0.117 & $(1.43)$ \\
\hline Ireland & 0.041 & $(1.71)$ & 0.052 & $(0.75)$ \\
\hline Italy & 0.219 & $(7.29)^{* *}$ & 0.092 & $(1.43)$ \\
\hline Cyprus & -0.036 & $(-1.32)$ & 0.077 & $(0.82)$ \\
\hline Latvia & -0.012 & $(-0.42)$ & 0.033 & $(0.46)$ \\
\hline Lithuania & -0.048 & $(-1.62)$ & -0.006 & $(-0.10)$ \\
\hline Luxemburg & -0.102 & $(-3.33)^{* *}$ & -0.113 & $(-1.55)$ \\
\hline Hungary & 0.055 & $(1.78)$ & -0.005 & $(-0.09)$ \\
\hline Malta & -0.074 & $(-2.60)^{* *}$ & -0.088 & $(-1.24)$ \\
\hline Netherlands & 0.131 & $(4.45)^{* *}$ & 0.098 & $(1.41)$ \\
\hline Austria & 0.114 & $(3.97)^{* *}$ & 0.096 & $(1.37)$ \\
\hline Poland & 0.055 & $(1.86)$ & 0.105 & $(0.86)$ \\
\hline Portugal & -0.025 & $(-0.87)$ & -0.005 & $(-0.09)$ \\
\hline Romania & -0.006 & $(-0.21)$ & 0.052 & $(0.86)$ \\
\hline Slovenia & -0.026 & $(-0.99)$ & 0.016 & $(0.21)$ \\
\hline Slovakia & -0.001 & $(-0.05)$ & 0.075 & $(0.98)$ \\
\hline Finland & 0.142 & $(5.07)^{* *}$ & 0.031 & $(0.27)$ \\
\hline Sweden & 0.152 & $(5.20)^{* *}$ & 0.063 & $(0.93)$ \\
\hline UK & 0.017 & $(0.62)$ & 0.018 & $(0.29)$ \\
\hline Croatia & -0.057 & $(-1.95)$ & -0.046 & $(-0.77)$ \\
\hline FYROM & 0.049 & $(1.77)$ & 0.103 & $(1.09)$ \\
\hline Turkey & -0.201 & $(-7.09)^{* *}$ & -0.122 & $(-2.23)^{*}$ \\
\hline Norway & 0.139 & $(4.91)^{* *}$ & 0.103 & $(1.50)$ \\
\hline Albania & -0.078 & $(-2.66)^{* *}$ & -0.101 & $(-1.34)$ \\
\hline Kosovo & 0.162 & $(5.54)^{* *}$ & 0.020 & $(0.26)$ \\
\hline Montenegro & 0.039 & (1.33) & -0.016 & $(-0.18)$ \\
\hline Constant & 1.320 & $(29.45)^{* *}$ & 1.469 & $(12.03)^{* *}$ \\
\hline Observations & \multicolumn{2}{|c|}{28965} & \multicolumn{2}{|c|}{4131} \\
\hline $\mathrm{R}^{2}$ & \multicolumn{2}{|c|}{0.061} & \multicolumn{2}{|c|}{0.066} \\
\hline
\end{tabular}

Note: Robust z-statistics in parentheses. "Significant at $5 \%$; ${ }^{* *}$ significant at $1 \%$. 
Table 3b. Dependent variable - Ln Happiness levels: Simultaneous results for regression models (after disaggregation by absolute nominal threshold)

\begin{tabular}{|c|c|c|c|c|}
\hline \multirow{2}{*}{$\begin{array}{l}\text { Variables } \\
\text { Pay cuts (decrease labor earnings) }\end{array}$} & \multicolumn{2}{|c|}{ Low/middle income group } & \multicolumn{2}{|c|}{ High income group } \\
\hline & -0.112 & $(-10.10)^{* *}$ & -0.065 & $(-3.24)^{* *}$ \\
\hline No change & 0.004 & $(0.51)$ & 0.012 & $(0.99)$ \\
\hline Males & 0.074 & $(10.68)^{* *}$ & 0.049 & $(3.56)^{* *}$ \\
\hline Age & -0.008 & $(-4.44)^{* *}$ & -0.021 & $(-4.47)^{* *}$ \\
\hline $\mathrm{Age}^{2}$ & 0.000 & $(2.88)^{* *}$ & 0.000 & $(4.50)^{* *}$ \\
\hline Primary education & -0.092 & $(-4.69)^{* *}$ & -0.005 & $(-0.09)$ \\
\hline Secondary education & -0.007 & $(-0.91)$ & 0.015 & $(1.02)$ \\
\hline Working hours & -0.001 & $(-3.80)^{* *}$ & -0.001 & $(-1.07)$ \\
\hline Low skilled manual & -0.118 & $(-9.66)^{* *}$ & -0.049 & $(-1.87)$ \\
\hline Low skilled clerical & -0.033 & $(-3.82)^{* *}$ & -0.017 & $(-1.25)$ \\
\hline High skilled manual & -0.048 & $(-4.09)^{* *}$ & 0.016 & $(0.66)$ \\
\hline Belgium & 0.054 & $(2.24)^{*}$ & 0.075 & $(1.08)$ \\
\hline Bulgaria & -0.077 & $(-2.25)^{*}$ & -0.151 & $(-1.01)$ \\
\hline Czech Republic & -0.116 & $(-3.90)^{* *}$ & 0.098 & $(0.99)$ \\
\hline Denmark & 0.175 & $(7.01)^{* *}$ & 0.207 & $(3.06)^{* *}$ \\
\hline Germany & 0.075 & $(3.04)^{* *}$ & 0.090 & $(1.24)$ \\
\hline Estonia & 0.061 & $(2.12)^{*}$ & 0.097 & $(1.02)$ \\
\hline Spain & 0.064 & $(2.43)^{*}$ & 0.131 & $(1.72)$ \\
\hline France & 0.188 & $(7.35)^{* *}$ & 0.187 & $(2.57)^{* *}$ \\
\hline Ireland & 0.025 & $(1.06)$ & 0.101 & $(1.44)$ \\
\hline Italy & 0.212 & $(7.16)^{* *}$ & 0.153 & $(2.17)^{*}$ \\
\hline Cyprus & -0.051 & $(-1.72)$ & 0.071 & $(0.90)$ \\
\hline Latvia & -0.036 & $(-1.03)$ & 0.107 & $(1.45)$ \\
\hline Lithuania & -0.046 & $(-1.53)$ & 0.069 & $(0.68)$ \\
\hline Luxemburg & -0.105 & $(-3.35)^{* *}$ & 0.071 & $(0.69)$ \\
\hline Hungary & 0.045 & $(1.48)$ & 0.064 & $(0.85)$ \\
\hline Malta & -0.083 & $(-2.89)^{* *}$ & 0.165 & $(1.82)$ \\
\hline Netherlands & 0.121 & $(4.46)^{* *}$ & 0.149 & $(2.05)^{*}$ \\
\hline Austria & 0.098 & $(3.40)^{* *}$ & 0.158 & $(2.28)^{*}$ \\
\hline Poland & 0.038 & $(1.36)$ & 0.134 & $(1.80)$ \\
\hline Portugal & -0.015 & $(-0.53)$ & 0.014 & $(0.15)$ \\
\hline Romania & 0.026 & $(0.87)$ & 0.211 & $(2.54)^{*}$ \\
\hline Slovenia & -0.034 & $(-1.22)$ & 0.027 & $(0.35)$ \\
\hline Slovakia & 0.001 & $(0.05)$ & 0.047 & $(0.52)$ \\
\hline Finland & 0.135 & $(5.63)^{* *}$ & 0.111 & (1.59) \\
\hline Sweden & 0.137 & $(5.38)^{* *}$ & 0.139 & $(2.00)^{*}$ \\
\hline UK & 0.004 & $(0.15)$ & 0.064 & $(0.88)$ \\
\hline Croatia & -0.044 & $(-1.57)$ & -0.024 & $(-0.29)$ \\
\hline FYROM & 0.038 & $(1.23)$ & 0.181 & $(2.21)^{*}$ \\
\hline Turkey & -0.156 & $(-5.43)^{* *}$ & 0.148 & $(1.99)^{*}$ \\
\hline Norway & 0.121 & $(4.49)^{* *}$ & 0.168 & $(2.39)^{*}$ \\
\hline Albania & -0.086 & $(-2.77)^{* *}$ & -0.094 & $(-0.99)$ \\
\hline Kosovo & 0.151 & $(5.29)^{* *}$ & 0.070 & $(0.79)$ \\
\hline Montenegro & 0.028 & $(1.01)$ & 0.073 & $(0.91)$ \\
\hline Constant & 1.323 & $(29.22)^{* *}$ & 1.501 & $(11.95)^{* *}$ \\
\hline Observations & \multicolumn{2}{|c|}{29239} & \multicolumn{2}{|c|}{3857} \\
\hline $\mathrm{R}^{2}$ & \multicolumn{2}{|c|}{0.058} & \multicolumn{2}{|c|}{0.052} \\
\hline
\end{tabular}

Note: Robust z-statistics in parentheses. "Significant at 5\%; " significant at 1\%.

Most of the predictors exhibited a significant relationship to (ln) happiness at $1 \%$ or $5 \%$ level. The predicted value is higher for males, which implies that women's happiness is less than that of men. With regards to age, a negative relationship to happiness is revealed. In addition, individuals with a high skilled clerical occupation and tertiary education have higher happiness 
levels. Moreover, longer working hours are associated with a decrease in the levels of happiness. Greece, being the omitted country, seems to have lower happiness levels than the Nordic countries, Kosovo and the Former Yugoslav Republic of Macedonia, while it seems to have higher happiness levels than the rest of the Balkan countries. Thus, the results provide a strong indication for the validity of the theoretical discussion concerning hierarchical needs, income levels and reported happiness.

At this point, it has to be noted that other factors might have played a role in determining the happiness level of Europeans, and may confound the pay cuts estimates. In particular, the aftermath of the Great Recession witnessed the Eurozone crisis, with large bailouts of countries and banks, and austerity policies. Apart from public service cuts, all these developments implied distrust towards national and European governments and institutions, and a general feeling of uncertainty and fear (Blanchflower \& Shadforth, 2009; Ehrmann et al., 2013). It can be argued that these negative effects might have been stronger for low income groups, thus strengthening the negative pay cuts effects of our study. However, given that our data is from 2010, the public service cuts effects took a relatively long period to be instituted and implemented, and therefore their effect exhibits a considerable lag compared to the pay cut effects.

Although the relevant literature on this topic is not very extensive, some prior empirical research on happiness in general provides some insights regarding the main variables (see Smith, 2015; Boyce et al., 2013). Our results indicate that males demonstrated higher levels of happiness than females. Previous evidence on gender differences and their associations with happiness has been inconsistent. The 2009 study by Stevenson and Wolfers showed that measures of subjective wellbeing suggest that women's happiness has declined both absolutely and relative to men, although a few studies report no gender differences (for instance, Louis \& Zhao, 2002; Liu et al., 2010). One of the main explanations for these results might be that women may simply find the complexity and increased pressure in their modern lives to have come at the cost of happiness (see also Ferber \& Green, 2003).

Furthermore, our findings point to a negative relationship between age and psychological wellbeing, which is consistent with other studies such as Van Praag et al. (2003) and Drakopoulos and Grimani (2013a). Many papers on the determinants of happiness and wellbeing, suggest a U-shaped relationship between age and wellbeing, where the youngest and the oldest are happiest, while the middle age groups are the least happy (see for instance: Blanchflower \& Oswald, 2008; Frijters \& Beatton, 2012; Drakopoulos \& Grimani, 2013b). One explanation here has to do with the higher expectations of the younger age group compared to older individuals (Clark \& Oswald, 1994; Gerdtham \& Johannesson, 2001). In addition, tertiary education and high skilled clerical employees were reporting the highest happiness levels (see for instance: Tsou \& Liu, 2001; Blanchflower \& Oswald, 2004; Drakopoulos \& Grimani, 2013a). A negative relationship was also found between working hours and happiness, suggesting that individuals who have longer work hours report lower happiness levels. The evidence is consistent with other empirical work, such as in Galay (2007). Finally, happiness is higher for Nordic countries and lower for southern contiguous countries compared to Greece (Huppert \& So, 2013; Drakopoulos \& Grimani, 2013b).

Our results can also be connected to research indicating that income is a very important happiness determinant for lower income groups (e.g., Layard et al., 2010). Furthermore, Corazzini et al. (2012) focused on the differences between high and low income countries regarding the strength of relative concerns. Their findings support the presence of relative concerns in the perception of wellbeing, with the strength of relativism being higher for respondents in high income countries. 


\title{
6. Conclusions
}

Falling labor earnings have been observed in many countries since the Great Recession. Given that there is not much work on this important issue, the main aim of this paper was to investigate the relationship between falling labor earnings and workers' happiness. The paper employed the psychological theory of hierarchical needs which has been applied to many economic contexts. The hierarchical structure of needs implies that the most important needs must be satisfied first before the secondary needs are considered. In the framework of the income-happiness relationship, the theory would predict that income is very important for happiness up to a certain level of income. For higher levels of income, income is still important but much less so, given that other factors affecting happiness come into the picture.

The paper utilized a large sample to test the above relationships by using data from 33 European countries and Turkey. In particular, the results indicate that pay cuts have a highly significant negative effect on the happiness levels of workers with low and middle income, implying that pay cuts reduce workers' happiness compared to those whose pay does not change or increase. The effect becomes much weaker for the workers belonging to higher income group when it comes to the disaggregation based on absolute nominal threshold.

The main empirical findings reveal different results between the two disaggregation methods. Disaggregation based on absolute nominal threshold supports the notion of the needs hierarchy and its relation to labor earnings. Labor earning changes seem to be more important for happiness for low and middle income group workers. Moreover, it seems that labor earning changes lose their importance for the high income workers' group, and this is consistent with the incorporation of the needs hierarchy into the context of happiness research. Furthermore, the above empirical findings link psychological wellbeing issues to financial loss, and this is consistent with other relevant studies. There is a large literature pointing out the importance of subjective wellbeing for labor productivity, organizational performance, absenteeism, and health and longevity (for a recent survey, see De Neve et al. 2013 and references therein). Our results provide additional insights to the above, given that low and middle income workers are likely to suffer more in terms of happiness loss when nominal wage cuts are applied. The fall of happiness of low income groups may have stronger adverse effects on their productivity, work performance, absenteeism and health levels. Nevertheless, there is a need for further research on understanding the above relationships, given that the relative threshold method did not provide the same support to the previous points.

\author{
Authors \\ Stavros Drakopoulos \\ National and Kapodistrian University of Athens \\ sdrakop@uoa.gr \\ Katerina Grimani \\ National and Kapodistrian University of Athens
}

\section{Publishing Timeline}

Received 22 June 2016

Accepted 27 February 2017

Published 9 June 2017 


\section{References}

Ahuvia, A. (2008). If money doesn't make us happy, why do we act as if it does? Journal of Economic Psychology, 29(4), 491-507. https://doi.org/10.1016/j.joep.2007.11.005

Bech, P. (1993). Rating scales for psychopathology, health status and quality of life: A compendium on documentation in accordance with the DSM-III-R and WHO systems. Berlin, Germany: Springer. https://doi.org/10.1007/978-3-642-77759-2

Blanchflower, D., \& Oswald, A. (2004). Well-being over time in Britain and the USA. Journal of Public Economics, 88, 1359-1386. https://doi.org/10.1016/S0047-2727(02)00168-8

Blanchflower, D., \& Oswald, A. (2008). Is well-being U-shaped over the life cycle? Social Science $\mathcal{E}$ Medicine, 66(8), 1733-1749. https://doi.org/10.1016/j.socscimed.2008.01.030

Blanchflower, D., \& Shadforth, C. (2009). Fear, unemployment and migration. The Economic Journal, 119, F136-F182. https://doi.org/10.1111/j.1468-0297.2008.02224.x

Boyce, C., Wood, A., Banks, J., Clark, A., \& Brown, G. (2013). Money, well-being and loss aversion: Does an income loss have a greater effect on well-being than an equivalent income gain? Psychological Science, 24(12), 2557-2562. https://doi.org/10.1177/0956797613496436

Camerer, C. (2000). Prospect theory in the wild: Evidence from the field. In D. Kahneman \& A. Tversky (Eds.), Choices, values, and frames (pp. 288-300). Cambridge, England: Cambridge University Press.

Canova, L., Rattazzi, A., \& Webley, P. (2005). The hierarchical structure of saving motives. Journal of Economic Psychology, 26, 21-37. https://doi.org/10.1016/j.joep.2003.08.007

Canterbery, R. (1979). Inflation, necessities and distributive efficiency. In J. Gapinski \& C. Rockwood (Eds.), Essays in post-Keynesian inflation (pp. 79-103). Cambridge, MA: Ballinger.

Charness, G., \& Grosskopf, B. (2001). Relative payoffs and happiness: An experimental study. Journal of Economic Behavior E Organization, 45(3), 301-328. https://doi.org/10.1016/S0167-2681(01)00148-2

Chattopadhyay, N., Majumder, A., \& Coondoo, D. (2009). Demand threshold, zero expenditure and hierarchical model of consumer demand. Metroeconomica, 60, 91-118. https://doi.org/10.1111/j.1467999X.2008.00323.x

Clark, A., Frijters, P., \& Shields, M. (2008). Relative income, happiness and utility: An explanation for the Easterlin paradox and other puzzles. Journal of Economic Literature, 46(1), 95-124. https://doi.org/10.1257/jel.46.1.95

Clark, A., \& Oswald, A. (1994). Unhappiness and unemployment. Economic Journal, 104(424), 648-659. https://doi.org/10.2307/2234639

Clark, A., \& Oswald, A. (1996). Satisfaction and comparison income. Journal of Public Economics, 61, 359381. https://doi.org/10.1016/0047-2727(95)01564-7

Corazzini, L., Esposito L., \& Majorano F. (2012). Reign in hell or serve in heaven? A cross-country journey into the relative vs absolute perceptions of well-being. Journal of Economic Behavior and Organization, 81, 715-730. https://doi.org/10.1016/j.jebo.2010.12.016

Cronbach, L. J. (1951). Coefficient alpha and the internal structure of tests. Psychometrica, 16(3), $297-334$. https://doi.org/10.1007/BF02310555

Cummins, R. A. (2000). Personal income and subjective well-being: A review. Journal of Happiness Studies, 1, 133-158. https://doi.org/10.1023/A:1010079728426

Danna, K., \& Griffin, R. W. (1999). Health and well-being in the workplace: A review and synthesis of the literature. Journal of Management, 25(3), 357-384. https://doi.org/10.1177/014920639902500305

Deci, E. L., \& Ryan, R. M. (2008). Hedonia, eudaimonia, and well-being: An introduction. Journal of Happiness Studies, 9(1), 1-11. https://doi.org/10.1007/s10902-006-9018-1

De Neve, J-E., Diener, E., Tay, L., \& Xuereb, C. (2013). The objective benefits of subjective well-being. In J. Helliwell, R. Layard, \& J. Sachs (Eds.), World happiness report 2013. New York, NY: UN Sustainable Development Solutions Network. Retrieved from http://cep.lse.ac.uk/pubs/download/dp1236.pdf

De Neve, J-E., Ward, G., De Keulenaer, F., Van Landeghem, B., Kavetsos, G., \& Norton, M. (2015). The asymmetric experience of positive and negative economic growth: Global evidence using subjective well-being data. https://doi.org/10.2139/ssrn.2506600

Diener, E., Oishi, S., \& Tay, L. (2013). Rising income and the subjective well-being of nations. Journal of Personality and Social Psychology, 104(2), 267-276. https://doi.org/10.1037/a0030487 
Dolan, P., Peasgood, T., \& White, M. (2008). Do we really know what makes us happy? A review of the economic literature on the factors associated with subjective well-being. Journal of Economic Psychology, 29(1), 94-122. https://doi.org/10.1016/j.joep.2007.09.001

Drakopoulos, S. (1994). Hierarchical choice in economics. Journal of Economic Surveys, 8, 133-153. https://doi.org/10.1111/j.1467-6419.1994.tb00097.x

Drakopoulos, S. (2013). Hierarchical needs, income comparisons, and happiness levels. In A. Efklides \& D. Moraitou (Eds.), A positive psychology perspective on quality of life (pp. 17-32). New York, NY: Springer.

Drakopoulos, S., \& Grimani, K. (2013a). Injury-related absenteeism and job satisfaction: Insights from Greek and UK data. The International Journal of Human Resource Management, 24(18), 3496-3511. https://doi.org/10.1080/09585192.2013.777678

Drakopoulos, S. A., \& Grimani, K. (2013b). Maslow's needs hierarchy and the effect of income on happiness levels. In F. Sarracino (Ed.). The happiness compass: Theories, actions and perspectives for wellbeing (pp. 295-309). New York, NY: Nova Science.

Drakopoulos, S., \& Grimani, K. (2015). The effect of pay cuts on psychological well-being and job satisfaction. In R. Osbourne (Ed.). Job satisfaction: Determinants, workplace implications and impacts on psychological well-being (pp. 113-126). New York. NY: Nova Science.

Drakopoulos, S., \& Theodossiou, I. (1997). Job satisfaction and target earnings. Journal of Economic Psychology, 18, 693-704. https://doi.org/10.1016/S0167-4870(97)00030-5

Easterlin, R. A. (1995). Will raising the income of all increase the happiness of all? Journal of Economic Behavior E Organization, 27(1), 35-47. https://doi.org/10.1016/0167-2681(95)00003-B

Easterlin, R. A. (2001). Income and happiness: Towards a unified theory. Economic Journal, 111, 465-484. https://doi.org/10.1111/1468-0297.00646

Easterlin, R., \& Angelescu, L. (2012). Modern economic growth and quality of life: Cross sectional and time series evidence. In K. Land, A. Michalos \& J. Sirgy (Eds.), Handbook of social indicators and quality of life research (pp. 113-136). New York, NY: Springer. https://doi.org/10.1007/978-94-007-2421-1 6

Ehrmann, M., Soudan, M. \& Stracca, L. (2013). Explaining European Union citizens' trust in the European Central Bank in normal and crisis times. The Scandinavian Journal of Economics, 115, 781-807. https://doi.org/10.1111/sjoe.12020

Ferber, M., \& Green, C. (2003). Career or family: What choices do college women have? Journal of Labor Research, 24, 143-151. https://doi.org/10.1007/s12122-003-1033-y

Ferrer-i-Carbonell, A. (2005). Income and well-being: An empirical analysis of the comparison income effect. Journal of Public Economics, 89(5), 997-1019. https://doi.org/10.1016/j.jpubeco.2004.06.003

Fordyce, M. (1988). A review of research on the happiness measures: A sixty second index of happiness and mental health. Social Indicators Research, 20(4), 355-381.

https://doi.org/10.1007/BF00302333

Frijters, P., \& Beatton, T. (2012). The mystery of the U-shaped relationship between happiness and age. Journal of Economic Behavior E Organization, 82(2-3), 525-542. https://doi.org/10.1016/j.jebo.2012.03.008

Galay, K. (2007). Patterns of time use and happiness in Bhutan: Is there a link between the two? (Visiting Research Fellows Series No. 432). Tokyo, Japan: Institute of Developing Economies, Japan External Trade Organization.

Gasper, D. (2005). Subjective and objective well-being in relation to economic inputs: Puzzles and responses. Review of Social Economy, 63(2), 177-206. https://doi.org/10.1080/00346760500130309

Gerdtham, U., \& Johannesson, M. (2001). The relationship between happiness, health, and socioeconomic factors: Results based on Swedish microdata. The Journal of Socio-economics. 30(6), 553-557. https://doi.org/10.1016/S1053-5357(01)00118-4

Gill, T. M., \& Feinstein, A. R. (1994). A critical appraisal of the quality of quality-of-life measurements. JAMA: The Journal of the American Medical Association, 272(8), 619-626. https://doi.org/10.1001/jama.1994.03520080061045 
Grant, A. M., Christianson, M. K., \& Price, R. H. (2007). Happiness, health or relationships? Managerial practices and employee well-being tradeoffs. Academy of Management Perspectives, 21(3), 51-63. https://doi.org/10.5465/AMP.2007.26421238

Green, W. H., \& Hensher, D. A. (2010). Modeling ordered choices: A primer. Cambridge, England: Cambridge University Press. https://doi.org/10.1017/CBO9780511845062

Greene, W. (2012). Econometric analysis (7th ed.). Boston, MA: Pearson.

Helliwell, J. (2003). How's life? Combining individual and national variables to explain subjective wellbeing. Economic Modelling, 20(2), 331-360. https://doi.org/10.1016/S0264-9993(02)00057-3

Huggett, M., \& Ventura, G. (2000). Understanding why high income households save more than low income households. Journal of Monetary Economics, 45, 361-397. https://doi.org/10.1016/S03043932(99)00058-6

Huppert, F. A. (2009). Psychological well-being: Evidence regarding its causes and consequences. Applied Psychology: Health and Well-being, 1(2), 137-164. https://doi.org/10.1111/j.1758-0854.2009.01008.x

Huppert, F. A., \& So, T. (2013). Flourishing across Europe: Application of a new conceptual framework for defining well-being. Social Indicators Research, 110(3), 837-861. https://doi.org/10.1007/s11205-011$\underline{9966-7}$

Jackson, T., \& Marks, N. (1999). Consumption, sustainable welfare and human needs - with reference to UK expenditure patterns between 1954 and 1994. Ecological Economics, 28, 421-441. https://doi.org/10.1016/S0921-8009(98)00108-6

Jenkins, S. P., Brandolini, A., Micklewright, J., \& Nolan, B. (2013). The Great Recession and the distribution of household income. Oxford, England: Oxford University Press.

Kahneman, D., \& Krueger, A. B. (2006). Developments in the measurement of subjective well-being. Journal of Economic Perspectives, 20(1), 3-24. https://doi.org/10.1257/089533006776526030

Kahneman, D., Krueger, A. B., Schkade, D., Schwarz, N., \& Stone, A. (2004). Toward national well-being accounts. The American Economic Review, 94(2), 429-434. https://doi.org/10.1257/0002828041301713

Kahneman, D., \& Tversky, A. (1979). Prospect theory: An analysis of decision under risk. Econometrica, 47(2), 263-291. https://doi.org/10.2307/1914185

La Placa, V., McNaught, A., \& Knight, A. (2013). Discourse on wellbeing in research and practice. International Journal of Wellbeing, 3(1), 116-125. https://doi.org/10.5502/ijw.v3i1.7

Layard, R., Mayraz, G., \& Nickell, S. (2010). Does relative income matter? Are the critics right? In E. Diener, J. Helliwell, \& D. Kahneman (Eds.). International differences in well-being (pp. 139-165). New York, NY: Oxford University Press. https://doi.org/10.1093/acprof:oso/9780199732739.003.0006

Liu, X., Thomas, S., \& Zhang, L. (2010). College quality, earnings, and job satisfaction: Evidence from recent college graduates. Journal of Labor Research, 31, 183-201. https://doi.org/10.1007/s12122-010$\underline{9086-1}$

Lluch, C., Powell, A., \& Ross, A. (1977). Patterns in household demand and saving. Oxford, England: Oxford University Press.

Louis, V., \& Zhao, S. (2002). Effects of family structure, family SES and adulthood experiences on life satisfaction. Journal of Family Issues, 23(8), 986-1005. https://doi.org/10.1177/019251302237300

Lyubomirsky, S., King, L., \& Diener, E. (2005). The benefits of frequent positive affect: Does happiness lead to success? Psychological Bulletin, 131(6), 803-855. https://doi.org/10.1037/0033-2909.131.6.803

Maslow, A. (1954). Motivation and personality. New York, NY: Harper and Row.

Max-Neef, M., (1995). Economic growth and quality of life: A threshold hypothesis. Ecological Economics, 15, 115-118. https://doi.org/10.1016/0921-8009(95)00064-X

Mentzakis, E., \& Moro, M. (2009). The poor, the rich and the happy: Exploring the link between income and subjective well-being. The Journal of Socio-Economics, 38, 147-158.

https://doi.org/10.1016/j.socec.2008.07.010

Morissette, R., \& Xuelin, Z. (2006). Revisiting wealth inequality. Perspectives on Labour and Income, 7(12), 516.

Murphy, B., Roberts, P., \& Wolfson, M. (2007). High income Canadians. Perspectives on Labour and Income, 8(9), 5-17. 
Novemsky, N., \& Kahneman, D. (2005). The boundaries of loss aversion. Journal of Marketing Research, 42(2), 119-128. https://doi.org/10.1509/jmkr.42.2.119.62292

Nunnaly, J. (1978). Psychometric theory. New York, NY: McGraw Hill.

Panos, G. A., \& Theodossiou, I. (2007). Earnings aspirations and job satisfaction: The affective and cognitive impact of earnings comparisons. Aberdeen, Scotland: Business School Working Paper Series.

Schutte, S., Chastang, J. F., Malard, L., Parent-Thirion, A., Vermeylen, G., \& Niedhammer, I. (2014). Psychosocial working conditions and psychological well-being among employees in 34 European countries. International Archives of Occupational and Environmental Health, 87(8), 897-907. https://doi.org/10.1007/s00420-014-0930-0

Senik, C. (2005). Income distribution and well-being: What can we learn from subjective data? Journal of Economic Surveys, 19(1), 43-63. https://doi.org/10.1111/j.0950-0804.2005.00238.x

Sisak, M., Varnik, A., Kolves, K., Konstabel, K. \& Wasserman, D. (2008). Subjective psychological wellbeing (WHO-5) in assessment of the severity of suicide attempt. Nordic Journal of Psychiatry, 62(6), 431-435. https://doi.org/10.1080/08039480801959273

Sloane, P. J., \& Williams, H. (2000). Job satisfaction, comparison earnings, and gender. Labour, 14(3), 473502. https://doi.org/10.1111/1467-9914.00142

Smith, J. (2015). Pay growth, fairness and job satisfaction: Implications for nominal and real wage rigidity. Scandinavian Journal of Economics, 117(3), 852-877. https://doi.org/10.1111/sjoe.12091

Steptoe, A., O'Donnell, K., Marmot, M., \& Wardle, J. (2008). Positive affect, psychological well-being, and good sleep. Journal of Psychosomatic Research, 64, 409-415. https://doi.org/10.1016/j.jpsychores.2007.11.008

Stevenson, B., \& Wolfers, J. (2009). The paradox of declining female happiness. American Economic Journal: Economic Policy, 1(2), 190-225. https://doi.org/10.1257/pol.1.2.190

Stutzer, A., \& Frey, B. (2010). Recent advances in the economics of individual subjective well-being. Social Research, 77, 679-714.

Tay, L., \& Harter, J. K. (2013). Economic and labour market forces matter for worker well-being. Applied Psychology: Health and Well-being, 5(2), 193-208. https://doi.org/10.1111/aphw.12004

Thiele, S., \& Weiss, C., (2003). Consumer demand for food diversity: Evidence for Germany. Food Policy, 28, 99-115. https://doi.org/10.1016/S0306-9192(02)00068-4

Topp, C. W., Ostergaard S. D., Sondergaard S., \& Bech P. (2015). The WHO-5 Well-Being Index: A systematic review of the literature. Psychotherapy and Psychosomatics, 84(3), 167-176. https://doi.org/10.1159/000376585

Tsou, M. G., \& Liu, J. T. (2001). Happiness and domain satisfaction in Taiwan. Journal of Happiness Studies, 2(3), 269-288. https://doi.org/10.1023/A:1011816429264

Van Praag, B. M. S., Frijters, P., \& Ferrer-i-Carbonell, A. (2003). The anatomy of subjective well-being. Journal of Economic Behavior \& Organization, 51(1), 29-49. https://doi.org/10.1016/S0167-2681(02)00140$\underline{3}$

Wesarat, P., Sharif, M. Y., \& Majid, A. (2015). A conceptual framework of happiness at the workplace. Asian Social Science, 11(2), 78-88.

Williams, R. (2008, June). Ordinal regression models: Problems, solutions, and problems with the solutions. Paper presented at the German State User Group Meetings, Indianapolis, IN. Retrieved from http://www.stata.com/meeting/germany08/GSUG2008-Handout.pdf

Wood, A. M., Boyce, C. J., Moore, S. C., \& Brown, G. D. A. (2012). An evolutionary based social rank explanation of why low income predicts mental distress: A 17 year cohort study of 30,000 people. Journal of Affective Disorders, 136(3), 882-888. https://doi.org/10.1016/j.jad.2011.09.014

World Health Organization (2011). Impact of economic crisis on mental health. Denmark: WHO Publications. 